\title{
The Influence of Information Integration on Hotel Performance through the Green Operation and Strategic Purchasing
}

\author{
Hotlan Siagian $^{1+}$, Zeplin Jiwa Husada Tarigan ${ }^{2,}$ and Fransisca Andreani ${ }^{3}$ \\ ${ }^{1,2,3}$ Petra Christian University, Surabaya, East Java, Indonesia
}

\begin{abstract}
Today, the tourism industry is one of the cores of the Indonesian economy. The growth of this industry has increased the number of a hotel located in the tourism place such as East Java of Indonesia. The rivalry among the hotel become unavoidable and even more intensified. On the other hand, the customer requirement has shifted to the environmental issue. Hence, the hotel's management has no choice other than to enhance the awareness of the management of environmental issues. This study examines the effect of information integration on hotel performance through strategic purchasing and the green operation. Data collection was performed by distributing 75 questionnaires representing 75 hotel. The respondents are the permanent employee involved in management levels such as supervisor or manager. The result suggested as follow: 1) The information integration affects the hotel performance,2) The information integration influence the strategic purchasing, 3) The information integration affects the green operation, 4) The strategic purchasing influences the green operation, 5) The strategic purchasing affects the hotel performance, 6) The green operation affect hotel performance. The additional finding from this research can be drawn as follow: 1). Strategic purchasing mediates the effect of information integration on the hotel performance, 2). Green operation mediates the effect of information integration on hotel performance. The study provides an insight for the manager on how to enhance hotel performance from the point of SCM (Supply Chain Management).
\end{abstract}

Keywords: Strategic Purchasing, Green Operation, Information Integration, and Hotel Performance.

\section{Introduction}

The foreign tourists are people who visit a country outside their place of residence, which is driven by one or several needs without intending to earn income at the place visited. Domestic tourists also reported experiencing an increase from 58.07 million visitors in 2016 up to 58.67 million visitors in 2017 [1]. This growth of the visitor has naturally pushed the growth in the accommodation industry such as hotel, transportation, and culinary. The hotel provides service for the customer through the interaction between the provider and the customer. A report by the East Java Culture and Tourism Office indicated the number of 3star, 4-star, and 5-star hotel amounted to 109 hotels in total. While in the year 2017, it increased to 117 hotels.

People are choosing the hotel for their need by considering several factors such as the location, price, and service quality and these factors become a competitive advantage of each hotel. Today, however, there has been increasing attention of the visitor to consider the environmental awareness of the hotel operation before deciding the choice. They prefer the hotel that operates in the way of environment-friendly. Environmentally friendly means that the hotel has paid attention to environmental sustainability in the hotel operation. Several operation aspects that reflect an environmental in a friendly way is the use of information technology, the application of green operation into daily practices and the implementation of strategic purchasing which procure material from the supplier which consider environmental sustainability. The green operation means that all employee has an orientation such as doing green purchasing, thinking about the environmental impact and pay attention to the safety and healthy work condition.

\footnotetext{
+ Corresponding author. Tel.: +62312983256
}

E-mail address: hotlan.siagian@petra.ac.id 
However, the question raised is how the issue of information technology, strategic purchasing, and green operation improve the performance of the hotel. There have been several studies in the literature reporting examine the extent to which the hotel performance is affected by the application of information technology and the adoption of strategic purchasing and the green operation. Chen et al., [2] stated that information integration within an organization could support strategic purchasing because it can provide cost efficiency for hotels. Strategic purchasing must be supported by information integration so that the purchasing department gets detailed and complete information from the information system obtained by the purchasing department. Information integration can accommodate the overall operational needs of the hotel regarding material and supporting material requirements based on the requested by the users.

Today, hotels management have implemented an integrated information system which enables them to make changes quickly and precisely. Information technology in hotels can build a green operation because it can reduce paper use significantly, can reduce the use of hazardous materials and be able to use substances that are environmentally friendly substances [3]. Strategic purchasing built by the company can provide a green operation with strong partnerships with suppliers and long-term planning built. Hotel management should include the purchasing department in building a long-term hotel planning process to synchronize the primary and supporting material need through green purchasing practices. Green employees and green processes within the hotel need to be considered in depth to provide efficiency and effectiveness for the hotel. Green operations that have been carried out by the hotel should be able to contribute to improving hotel performance. The above description has shown that several studies have been performed to investigate the relationship of information integration, hotel performance, and strategic purchasing. So far, however, there has been little discussion about the effect of the green operation on the hotel performance and its relationship with information integration and strategic purchasing.

\section{Theoretical Review}

\subsection{Hotel performance}

Organizational performance for hotels is defined as the achievement of the organization in a certain period. Hotels always try to maintain the performance achieved, to be able to compete with other hotels. The hotel is always trying to make certain improvements and developments to be able to increase the benefits of the hotel. The hotel performance is divided into two categories, namely financial performance, and nonfinancial performance. Financial performance is measured by liquidity ratios, solvency ratios, activity ratios, and profitability ratios. Non-financial performance can be seen from hotel occupancy, some hotel occupancy, hotel user satisfaction, hotel service quality and hotel brand image [4]. This research measure the performance of hotels in conducting operations or nonfinancial performance using five indicators namely 1) the timely checking-in process, 2) the increased responsiveness to customers demand, 3) decreased customer complaints rate, 4) the improved of service quality, 5) the quick check-out process time.

\subsection{Information integration}

Information technology can provide information about the profile of the hotel resources and help employees carry out their work in the best performance. In the front-office of the hotel, information integration can be seen in the front some information such as the number of rooms filled, the number of rooms available, and the information that customers do through booking online systems [5]. Information integration is used in services and transactions with the customers in using the company's system. Hotels can use information integration to reduce operational costs associated with transaction costs resulting in increased company performance [6]. Similarly, the implementation of the information integration by the hotel also improve employee productivity and customer satisfaction [5]. Information technology in hotels can build a green operation because it can reduce paper use significantly, can reduce the use of hazardous materials and use environmentally friendly substances [3]. Hotels can reduce waste and use facilities and infrastructure that are friendly to the environment and use equipment repeatedly.

Another research by Chen et al., [2] stated that six integration within an organization could support strategic purchasing because it can provide cost efficiency. Strategic purchasing needs supported such as information integration in providing the purchasing department detailed and complete information about 
what material or service to purchase. Information integration can accommodate the overall operational needs of the hotel regarding material and supporting material requirements based on the requested by the users and approved by hotel management. Strategic purchasing focuses on cross-functional communication and the relationship between the organization and the suppliers. On this study information integration defined as the extent to which the hotel has implemented the information integration and is assessed using four indicators: 1 ) data integration within the organization is running well, 2) reports are updated on time, 3) users can access on time, and 4) maintenance data can be done online. From the discussion three hypotheses:

H1. Information integration affects hotel performance.

$\mathrm{H} 2$ : Information integration influence strategic purchasing

H3: Information integration affect the green operation

\subsection{Strategic purchasing}

Purchasing is a process to obtain the goods and services needed by the organization. The selection of the strategy or technique for the company to procure material and supporting material on an ongoing basis is called a purchasing strategy. Strategic purchasing orientation always focuses on critical suppliers and suppliers who can collaborate in the long term [7]. The indicator used in strategic purchasing in this study was to see whether the purchasing department's strategies were in line with the strategic goal set by the hotel management. The indicator used is purchasing is 1) purchasing involve in the strategic planning process, 2) purchasing department understands well the strategic objective, 3) purchasing department is part of the management team, and 4) purchasing department develop a long-term procurement planning. Strategic purchasing has a better impact on the company's system of integration with suppliers and can be valid for an extended period. The purchasing strategy has an impact on the company's operational performance with the value chain between buyers and suppliers [8]. Green purchasing is a company business in carrying out purchasing activities are carried out in support of environmental sustainability goals such as the use of goods with minimum waste, recycling, reuse and replacement of hazardous and toxic materials [9]. Hence, strategic purchasing will support the implementation of the green operation. The hypotheses are proposed:

H4: Strategic purchasing influence the green operation.

H5: Strategic purchasing affect hotel performance

\subsection{Green operation}

Green operation related to green purchasing is the purchase of materials that include reduction, reuse, and substitution of materials that are not environmentally friendly with environmentally friendly materials. The green operation system can also be used to monitor processes that are focused on environmental issues such as reduce paper, reduce the use of electricity, and use materials that can be recycled and reuse [10]. The green process is a production process or service that has minimal impact on the environment, occupational safety and health. Green processes always pay attention to internal conditions in the application of appropriate technology to achieve adequate process conditions in business value [11]. Green employee is an understanding of all members of the organization in thinking patterns, attitudes and actions that are environmentally friendly in carrying out activities and are always guided by occupational safety and health norms. Finally, green marketing is an activity about services provided to customers to provide customer satisfaction that does not have an impact on the environment. Dubey et al. [12] advised that manufacturing companies are needed to cooperate with raw material suppliers in producing environmentally friendly products. Because the company has the right as a customer of its suppliers, the organization has the authority to determine the criteria for environmentally friendly raw materials to be used. The indicator used to measure green operation is 1) the purchasing of the material focuses on green, 2) employees do work thinking about environmental, 3) employees do work paying attention, 4) the hotel focuses on green marketing, and 5) use technology information as an activity. Last revision, H6: Green operation influence the hotel performance

\section{Research Method}

The type of this research is an explanatory study which is used to carry out to examine the influence of one variable on other variables. The data collection was performed by using a questionnaire distributed to 
various hotels in the East Java region. The population of this study is all hotel registered in the East Java culture and tourism service covering three stars, four stars, and five stars with the total number is 265 hotels. The number of samples is determined to a minimum of 45 hotels (greater than ten times the number of variables). Seventy-five questionnaires were distributed with the expectation that a minimum of 45 questionnaires obtained. The respondents are the permanent staff who have been in charge of the management such as supervisor and manager level as they are considered knowledgeable about the hotel operational process. The data analysis uses Partial Least Square (PLS) with Smart PLS version 3. The first analysis is to assess the measurement model (outer model) by evaluating the convergent and discriminant validity of each indicator and the reliability of the block indicators of each variable. The next step is to examine the structural model (inner model) through the assessment of the patch coefficient together with its p-value or t-value. Table 1 lists the factor loading and cross loading of all indicators. Each indicator has a factor loading higher than the recommended minimum of 0.50 in all cases (range 0.653 to 0.873 ). Hence, all indicators are considered valid.

Table 1: Indicators factor loading and cross loading

\begin{tabular}{|c|c|c|c|c|c|}
\hline \multirow{2}{*}{ Variable \& Indicator } & \multicolumn{4}{|c|}{$\begin{array}{l}\text { Factor Loading (bold) } \\
\text { and Cross Loading }\end{array}$} & \multirow[t]{2}{*}{ Validity } \\
\hline & $\mathbf{X} 1$ & $\mathbf{X} 2$ & X3. & Y1 & \\
\hline \multicolumn{6}{|l|}{ Information Integration (X1) } \\
\hline 1. Data integration running well (X1.1) & 0.695 & 0.258 & 0.441 & 0.533 & Valid \\
\hline 2. Reports are updated on time (X1.2) & 0.725 & 0.062 & 0.490 & 0.418 & Valid \\
\hline 3. The user can access data on time (X1.3) & 0.825 & 0.270 & 0.493 & 0.518 & Valid \\
\hline 4. Maintenance data can be done online (X1.4) & 0.729 & 0.318 & 0.488 & 0.677 & Valid \\
\hline \multicolumn{6}{|l|}{ Strategic Purchasing (X2) } \\
\hline Purchasing depart. involve in the strategic decision (X2.1) & 0.066 & 0.653 & 0.391 & 0.276 & Valid \\
\hline Purchasing depart. understand the Org. objective (X2.2) & 0.272 & 0.708 & 0.396 & 0.446 & Valid \\
\hline Purchasing depart. is part of the management team (X2.3) & 0.346 & 0.842 & 0.235 & 0.464 & Valid \\
\hline Purchasing depart. develop long term procurement (X2.4) & 0.230 & 0.786 & 0.314 & 0.382 & Valid \\
\hline \multicolumn{6}{|l|}{ Green Operation (X3) } \\
\hline Purchasing material focuses on green purchasing (X3.1) & 0.411 & 0.211 & 0.708 & 0.539 & Valid \\
\hline Employees think about environmental impacts (X3.2) & 0.554 & 0.424 & 0.873 & 0.661 & Valid \\
\hline Employees pay attention to safety and healthy (X3.3) & 0.52 & 0.383 & 0.778 & 0.613 & Valid \\
\hline The hotel front-office focuses on green marketing (X3.4) & 0.498 & 0.326 & 0.734 & 0.518 & Valid \\
\hline \multicolumn{6}{|l|}{ Hotel Performance (Y1) } \\
\hline The timely checking of check-in linking (Y1.1) & 0.403 & 0.342 & 0.621 & 0.694 & Valid \\
\hline The response to hotel customers is increasing (Y1.2) & 0.430 & 0.524 & 0.508 & 0.711 & Valid \\
\hline The level of service complaints is decreasing (Y1.3) & 0.573 & 0.435 & 0.488 & 0.801 & Valid \\
\hline The quality of hotel services is increasing (Y1.4) & 0.569 & 0.288 & 0.643 & 0.685 & Valid \\
\hline The reported linkage checks out is the right time (Y1.5) & 0.650 & 0.335 & 0.445 & 0.695 & Valid \\
\hline
\end{tabular}

Table 1 also lists the indicators cross loading which indicates that each indicator has cross loading value higher with its construct than with others. It shows that all indicators are valid in term discriminant validity. Table 2 lists the value of reliability of the measurement model as shown by Cronbach Alpha (C/A), composite reliability (CR), Rho Alpha, and the Average Variance Extracted (AVE). Those variables have a value higher than 0.70 for C/A. C/R, Rho Alpha in all cases (range 0.733 to 0.857 ). While the value of AVE exceeded the recommended minimum value of 0.50 in all cases (range 0.516 to 0.602 ).

Table 2: Reliability of Measurement Model

\begin{tabular}{lccccc}
\hline \multicolumn{1}{c}{ Variable } & C/A & rho_A & C/R & AVE & $\mathrm{R}^{2}$ \\
\hline Information Integration & 0.733 & 0.737 & 0.832 & 0.555 & - \\
Strategic Purchasing & 0.739 & 0.750 & 0.836 & 0.563 & 0.102 \\
Green Operational & 0.777 & 0.791 & 0.857 & 0.602 & 0.475 \\
Hotel Performance & 0.764 & 0.765 & 0.842 & 0.516 & 0.720 \\
\hline
\end{tabular}

Those results demonstrated that the measurement model has good validity and reliability in all cases. Table 2 also demonstrated the value of $\mathrm{R}$ square. Inner model assessment using PLS does not directly calculate the goodness of fitness. The primary method used to assess the inner model is by considering the variance explained called $\mathrm{R}$ square. The Greater value of $\mathrm{R}^{2}$ indicates a higher variance of the construct 
explained by the independent variable. This value indicates the portion of the variance of the dependent variable explained by the independent variable.

\section{Analysis and Result}

The next analysis is to assess if the data support the hypotheses. The hypotheses are examined by assessing the $t$-value of each path coefficient which reflects the relationship of the construct.

Table 3: Path Coefficient and T-Statistic

\begin{tabular}{lccc}
\hline \multicolumn{1}{c}{ Hypothesis } & Original (O) & T Statistics & Remarks \\
\hline Information Integration -> Strategic Purchasing (H1) & 0.387 & 2.303 & Supported \\
Information Integration -> Green Operational (H2) & 0.558 & 4.775 & Supported \\
Information Integration -> Hotel Performance (H3) & 0.414 & 3.163 & Supported \\
Strategic Purchasing -> Green Operational (H4) & 0.320 & 2.070 & Supported \\
Strategic Purchasing -> Hotel Performance (H5) & 0.263 & 2.102 & Supported \\
Green Operational -> Hotel Performance (H6) & 0.231 & 2.615 & Supported \\
\hline
\end{tabular}

Table 3 above shows the value of each path coefficient with its T statistic. For the significance level of 5\% or $t$-value of 1.96, the results indicated that those path coefficients are positive with the $\mathrm{T}$ statistic value higher than 1.96 in all cases (range of 2.07 to 4.775). This result of analysis support and reinforce all the six hypotheses (H1 to H6). As all the hypotheses are supported, it also proves that strategic purchasing and the green operation mediate the relationship between information integration and hotel performance.

The primary goals of the present study are to investigate the effect of information integration on the hotel performance through the mediating role of strategic purchasing and the green operation. The results reinforce all the six proposed hypotheses. First hypotheses stated that information integration indeed affects the hotel performance. In the hotel management practice, this relationship is taking place mainly in the hospitality industry in the region of east java Indonesia. Information integration is reflected in the form of data integration across the department, on time data updating, data accessibility by the employee, and the maintenance of the data will improve the hotel performance. The main point in this finding is that data availability will enable proper and appropriate decision making in the sense of serving customer satisfaction and at the end improve the performance. Second hypotheses are also supported in this study. Information integration affects strategic purchasing [2]. The data integration across the department, on time data updating, data accessibility by the employee, and the maintenance of the data allow the purchasing department to establish an agreement with the supplier by hotel requirement and objective and develop an appropriate longterm procurement agreement.

Third hypotheses are stating that information integration influence the green operation is proved on this study. Information integration supports the organization to adopt the green operation into practice [3]. The use of information technology enables the operation of the hotel paperless. Elimination of the paper in the operation of the hotel is part of the green operation. The information integration also enables the hotel to communicate to the customer and the supplier without the use of the paper. The fourth hypotheses, which states that strategic purchasing affect the green operation is supported. The position of the strategic purchasing in the management team enable the purchasing department to select the supplier, which adopts environmentally friendly practices into their operational activity. Supplier holds an essential role in realizing the green operation and the strategic purchasing department should establish environmental awareness as one of the supplier criteria. The fifth hypotheses are stating that strategic purchasing influence hotel performance. It is clear, as the strategic purchasing focuses on the long-term agreement with the limited supplier, the company will benefit the cost efficiency from the material or service procurement, and at the end, improve the performance. This research supports the result of another research by Tarigan [13], which states the implementation of the innovation process enabling organizations to increase their operational performance.

The last hypotheses state that green operation affects hotel performance. Green operation adopts the paperless operation and replaced by the online information integration. Adopting the green operation enable the employee to practice environmentally friendly activity, and it is believed the customer will feel comfortable and enjoy the stay in the hotel. An exciting and notable finding from this study is the presence 
of the mediating role of the strategic purchasing and green operation in the relationship of the information integration on the hotel performance. Information integration affects hotel performance indirectly through the green operation and strategic purchasing. When the hotel adopts the strategic purchasing and the green operation, the impact of information integration on the performance is greater due to the indirect influence.

\section{Conclusion}

The main finding can be summarized as follow: 1.the information integration affects the hotel performance, 2) the information integration influences the strategic purchasing, 3) the information integration affects the green operation, 4) the strategic purchasing influences the green operation, 5) the strategic purchasing affects the hotel performance, 6) the green operation affects the hotel performance. The additional finding from this research can be drawn as follow: 1). strategic purchasing mediates the effect of information integration on the hotel performance, 2), green operation mediates the effect of information integration on the hotel performance. This study provides an insight for the manager how to enhance the hotel performance from the point of view supply chain management. This study also makes several contributions to the current literature in supply chain management. This study focuses on the hospitality industry. Hence, it is recommended that further research is undertaken in the other area such as the manufacturing industry which use substantial hazardous material and often damaged environmental stability.

\section{References}

[1] Rachmawati, A.N. Kunjungan Wisatawan Mancanegara Asing ke Jatim Meningkat Diakibatkan Banyaknya Obyek Wisata Baru, tribunjatim.com, 5 Agustus 2018.

[2] Chen, C.-J. Information Technology, Organizational Structure, and New Product Development---The Mediating Effect of Cross-Functional Team Interaction. IEEE Transactions on Engineering Manag. 2007, 54 (4): 687-698.

[3] Fang, C. and Zhang, J. Performance of Green Supply Chain Management: A Systematic Review and MetaAnalysis. Journal of Cleaner Production, 2018, 183: 1064-1081.

[4] Santoro, G. Evaluating Performance in the Hotel Industry: An Empirical Analysis of Piedmont, Journal of Investment and Management, 2015, 4(1-1): 17-22

[5] Oltean, F.D., Gabor, M. R. and Contiu, L.C. Relation between Information Technology and Performance: An Empirical Study Concerning the Hotel Industry in Mures County, Procedia Economic and Finance, 2014, 15: 1535-1542.

[6] Chathoth, P.K., The Impact of Information Technology on Hotel Operations, Service Management and Transaction Costs: A Conceptual Framework for Full-service Hotel Firms, International Journal of Hospitality Management, 2007, 26 (2): 395-408.

[7] Pressey, A., Tzokas, N., and Winklhofer, H. Strategic Purchasing and the Evaluation of "Problem" Key Supply Relationships: What do Key Suppliers Need to Know, Journal of Business \& Industrial Marketing, 2007, 22 (5): 282-294.

[8] Paulraj, A., Chen, I.J., and Flynn, J. Levels of Strategic Purchasing: Impact on Supply Integration and Performance, Journal of Purchasing and Supply Management, 2006, 12 (3): 107-122.

[9] Younis, H., Sundarakani, B., and Vel, P. The Impact of Implementing Green Supply Chain Management Practices on Corporate Performance, Competitiveness Review, 2016, 26 (3): 216-245.

[10] Meacham, J., Toms, L., Green Jr, K.W., and Bhadauria, V.S. Impact of Information Sharing and Green Information Systems, Management Research Review, 2013, 36 (5): 478-494.

[11] Y.-C. Huang, M. Yang and Y.-C. Wang. Effects of Green Brand on Green Purchase Intention, Marketing Intelligence \& Planning, 2012, 32 (3): 250-268.

[12] R. Dubey, S. Bagpp, S. S. Ali, and V. Venkatesh. Green Purchasing is Key to Superior Performance: An Empirical Study, International Journal Procurement Management, 2013, 6 (2), 187-210.

[13] Tarigan, Z.J.H. The Impact of Organization Commitment to Process and Product Innovation in Improving Operational Performance, International Journal of Business and Society, 2018, 19 (2), 335-346. 